Article

\title{
Impact of Institutional Support on Export Performance
}

\author{
Mário Nuno Mata ${ }^{1,2}$, Mohammad Falahat ${ }^{3, * \mathbb{D}}$, Anabela Batista Correia ${ }^{1}$ (D) and João Xavier Rita ${ }^{1}$ (D) \\ 1 ISCAL-Instituto Superior de Contabilidade e Administração de Lisboa, Instituto Politécnico de Lisboa, \\ Avenida Miguel Bombarda 20, 1069-035 Lisbon, Portugal; mnmata@iscal.ipl.pt (M.N.M.); \\ ambatista@iscal.ipl.pt (A.B.C.); jmrita@iscal.ipl.pt (J.X.R.) \\ 2 Polytechnic Institute of Santarém, School of Management and Technology (ESGTS-IPS), \\ 2001-904 Santarém, Portugal \\ 3 Department of International Business, Universiti Tunku Abdul Rahman (UTAR), Bandar Sungai Long, \\ Kajang 43000, Malaysia \\ * Correspondence: falahat@utar.edu.my
}

Citation: Mata, Mário Nuno,

Mohammad Falahat, Anabela Batista Correia, and João Xavier Rita. 2021. Impact of Institutional Support on Export Performance. Economies 9: 101. https://doi.org/10.3390/ economies 9030101

Academic Editor: Roberta Arbolino

Received: 5 April 2021

Accepted: 29 June 2021

Published: 3 July 2021

Publisher's Note: MDPI stays neutral with regard to jurisdictional claims in published maps and institutional affiliations.

Copyright: (c) 2021 by the authors. Licensee MDPI, Basel, Switzerland. This article is an open access article distributed under the terms and conditions of the Creative Commons Attribution (CC BY) license (https:// creativecommons.org/licenses/by/ $4.0 /)$.

\begin{abstract}
This paper examines institutional support (financial and marketing support) on exportoriented firms' performance or so-called born globals. We develop a model to address how financial and marketing support can help young entrepreneurial firms to overcome the liability of newness and smallness in gaining competitive capabilities. Using a quantitative method, data were collected from 217 manufacturers and service sectors in Malaysia, an emerging Southeast Asian market. The results suggest that government assistance in marketing leads to competitive capabilities and export performance; however, financial support neither contributes to competitive capabilities nor export performance. We found the significant role of competitive capabilities as a mediator in enhancing the relationship between marketing support and export performance. Practical implications drawn from this result can be offered as guidelines for the policymakers in supporting young entrepreneurs that lead to competitive capabilities and superior performance.
\end{abstract}

Keywords: institutional support; government assistance; export assistance; financial support; marketing support; competitive capabilities; export performance

\section{Introduction}

Due to globalisation, small and medium enterprises (SMEs) are able to internationalise from an early point. SMEs play a vital role in a nation's economic development. In almost every nation, a growing percentage of SMEs' income is derived from the overseas market. Those SMEs looking for internationalisation need to build up their own distinctive, unique and dynamic competencies to gain distinctive competitive strategies that enable them to compete against other firms, particularly when confronting bigger and better-enriched multinational enterprises (MNEs). Maintaining competitiveness and expanding business internationally are getting challenging especially in the global market. This competition in the worldwide markets and rising expectations from the global customers will continue to drive transformation in SMEs to become more technology-savvy, efficient and resilient, and later sustain its momentum (De Chiara and Minguzzi 2002).

SMEs are frequently facing difficulties in obtaining capital or financial resources in the early start-up phase (Ahmed et al. 2002). These difficulties in acquiring assets have likewise reduced their access to new technologies or innovation. Although SMEs have a crucial role in building up the nation's economy, they are frequently restricted financially by the absence of development support (Badulescu 2010).

SMEs must become regionally, if not globally competitive, to survive in increasingly competitive markets (Lee et al. 2020). To become regionally and globally competitive, SMEs must develop both the necessary and adequate resources and capabilities for achieving essential competitiveness (Lee et al. 2019; Kolarov and Georgieva 2020). In today's era of 
globalisation, more and more firms are striving to have a presence in the international market even though there are pressing challenges in going internationally (Zain and $\mathrm{Ng} 2006$ ).

Export-oriented firms or so-called born globals have been widely investigated in developed countries with advanced economies, but little research has been devoted to newly industrialised economies such as Malaysia. SMEs in Malaysia are involved in crossborder trade and export activities, but the percentage of SMEs that export their products or services are constant (around 20-25\%) over the past few years (Falahat et al. 2020b). SMEs from newly industrialised economies face internationalisation challenges due to the absence of assets, resources, and capabilities to exploit the competitive capabilities (Falahat et al. 2020a). Some may succeed internationally, yet there are many failures. Thus, SMEs from newly industrialised economies such as Malaysia are in favour of institutional support and needs to receive government support assistance to make them competitive for internationalisation. Thus, we aim to examine the effectiveness of marketing and financial assistance as the form of institutional support in gaining competitive capabilities for SMEs to expand overseas.

The remainder of the article is organised as follows: the next section presents the literature and hypotheses, followed by methods and data analysis derived from 217 Malaysian manufacturers and service sectors. The results and discussion are outlined and end with the conclusion.

\section{Literature Review}

\subsection{Theoretical Foundations}

The internationalisation procedure/stages theory demonstrates that a firm's export activities will not happen immediately and develop through stages (Albaum et al. 1998). There are two well-known models in clarifying the internationalisation process which is the Uppsala Internationalization Process model (Johanson and Wiedersheim-Paul 1975; Johanson and Vahlne 1990), and the Innovation-Related Internationalisation model (Cavusgil 1980; Bilkey and Tesar 1977; Naidu and Rao 1993; Reid 1981; Czinkota 1994).

The Uppsala Internationalisation model (Johanson and Vahlne 1990; Johanson and Wiedersheim-Paul 1975) implies four distinct stages of gradually increasing foreign involvement to becoming fully internationalised. Those four stages are no consistent export, export via traders; setup subsidiary office; and last, foreign direct investment for production. The Uppsala Internationalisation model's process focuses on knowledge of a firm about foreign markets and management commitment to these markets. This model assumes that management will have a high commitment to allocating resources to a market when they have more experiential knowledge through unsolicited exporting. In order to increase the management commitment factor such as the government policy for promoting international markets will affect internationalisation's strategic decision.

The Innovation model (Bilkey and Tesar 1977; Cavusgil 1980; Crick 1995; Naidu and Rao 1993; Reid 1981) suggests that internationalisation is a gradual process of acquiring innovations within the firm. It will then gradually acquire relevant knowledge and experience similar to the Uppsala model.

The field of international entrepreneurship (IE) has been rapidly developing for the past three decades. Zahra and George (2017) suggested that the focus of internationalisation has been on three issues: the extent and degree of internationalisation, the speed of internationalisation, and the scope of internationalisation. IE scholars strive to identify the drivers for international performance. Hagen and Zucchella (2014) group these drivers into three main categories, e.g., (1) entrepreneur characteristic (2) firm's internal environment and (3) firm's external environment. External factors such as globalisation, digitalisation, and industry-specific factors are homogeneous to firms from similar backgrounds, but the entrepreneur characteristic and firm's internal factors determine how they would respond to the external forces beyond their control. On the other side, forces affecting early internationalisation vary from one region to another because of the heterogeneous factors 
such as domestic market competition, government policy, country image, infrastructure condition etc.

Rennie (1993) first described the phenomenon of BG and received great attention within the international entrepreneurship field of study. Nevertheless, findings for BG internationalisation are fragmented, and limited studies are examining the effect of institutional support on young entrepreneurial firms (Hassan et al. 2019; Falahat et al. 2018a). In the following sections, we discuss the effect of institutional support such as government assistance in contributing to competitive capabilities and export performance.

\subsection{Government Assistance: Financial Support}

According to Durmuşoğlu et al. (2012), financial assistance can be measured with factors such as lower taxes, export loans at lower than market rates, duty-free import/export provisions and cash incentives. Financial-related information and knowledge are essential to a firm's capability in adapting to the foreign market environment (Cavusgil and Zou 1994; Morgan et al. 2004).

According to Hoque (2018), when SMEs are compared to larger firms, SMEs have a cost disadvantage due to their smaller size and do not have the same capability to motivate a favourable environment in the market (Oboreh et al. 2013; Rufaidah 2017, 2019). Moreover, SMEs cannot bear the costly support services such as human resources and training and financial and legal activities (Egena et al. 2014). Thus, the growth of SMEs largely depends on government assistance to allows them to consistently grow, overcome crises and survive in the competitive globalised business world (Iweka et al. 2016).

Based on research by Kotabe and Czinkota (1992), the availability of export financing assistance is crucial for early internationalising SMEs in their exporting involvement. Unfortunately, many SMEs are unable to seize capital from commercial banks due to their firm size and lack of experiences (Beck et al. 2008; Tannous 1997). Therefore, this caused SMEs to shift their financial dependency on government aid (Zia 2008).

According to Ahmad and Xavier (2002), studies have shown that SMEs usually are more aware of financial assistance than non-financial assistance. Such financial support assistance programs for SMEs have been established in many countries. In Malaysia's case, in the year 2017, a total of 2836 companies were approved for financial assistance amounting to RM2.44 billion (National SME Development Council 2015). The SME Corporation Malaysia also launched "SME Emergency Funds (SMEEF)" to support SMEs affected by bankruptcy. With the collaboration of SME Corporation and the Malaysian government by allocating RM10 million, SMEEF provides financing of up to a maximum of RM100,000 per company, in a hybrid form comprising both grants and soft loans which depending on the needs and capacity of the SMEs.

Other than capital loans, financial assistance from the government is also provided through direct and indirect subsidies, for example, exchange rate, fiscal incentives, and value-added tax exemption (Baumann and Braga 1988; Chen et al. 2006). In Malaysia, financial assistance includes credit consultancy, financial advice, and tax incentives provided by Credit Guarantee Corporation (CGC), Ministry of International Trade and Industry (MITI) and Malaysia External Trade Development Corporation (MATRADE).

\subsection{Government Assistance: Marketing Support}

Export assistance refers to all public policy measures that actually or potentially enhance exporting activity either from a firm, industry, or national perspective (Seringhaus 1986). According to Gençtürk and Kotabe (2001), export assistance is classified into two categories: financial and marketing support. Marketing support can then be classified as either standardised or customised marketing (Diamantopoulos and Hart 1993). According to Gençtürk and Kotabe (2001), standardised information is general in nature and available in hard copies available at selected government agencies, embassies, or trade missions. 
Next, market information relating to competitors, firms' customers and channels in the industry is an essential knowledge resource for early internationalisation (Katsikeas 1994; Souchon and Diamantopoulos 1996; Yeoh 2000; Martinez-Conesa et al. 2017).

As indicated by Morgan and Vorhies (2005), government assistance in marketing implementation for SMEs is imperative where it helps the routines by which export ventures transform intended export marketing strategy into acknowledged activities and asset arrangements.

In summary, marketing support was measured based on building up contact with buyers in export markets, providing information about export markets such as trends, trade agreements, and other related matters about government-sponsored trade missions (Durmuşoğlu et al. 2012).

\subsection{Competitive Capabilities}

Competitive capabilities are a prerequisite for any firm that wishes to explore international markets. Firms must possess the capabilities to create and maintain their competitive advantage in the target market to promote their products or services (Falahat et al. 2021). Penrose (1959) stated that the widely accepted framework for describing how a firm can develop a competitive capability is the resource-based view (RBV) of firm strategy.

The RBV views a firm as a combination of unique resources either in tangible or intangible form, enabling the firm to develop appropriate planning and strategies for enhancing its effectiveness and efficiency (Barney 1991; Wernerfelt 1984). According to Barney (2012) based on RBV, competitive advantage is attained only when resources are valuable, rare, inimitable. According to Freeman (2007), RBV offers a greater understanding and richer perspective for recognising the value of the firms' resources and capabilities. Usually, managers' willingness to seek government assistance on export market information, foreign trade missions, trade shows and sales leads can fill their firms' resources gap (Indrawati et al. 2018). This shows that a manager utilises internal resources for better performance and looks for opportunities through collaboration with the government in exploiting foreign market opportunities.

In general, competitive capability is a strategic factor that focuses on internal resource utilisation and fosters resource mobilisation from external sources. When the competitive advantage is achieved, it is a long-lasting positive capability that held the firm competitive in the export market (Navarro et al. 2010). Government agencies often become the most readily available external resources for assisting firms to export.

\section{Hypotheses Development}

\subsection{Financial Support and Export Performance}

The accessibility to financial resources is fundamental to export success (Morgan et al. 2004). Working capital and financial liquidity are critical to fulfilling the need for export operations (Griffith and Czinkota 2012; Morgan et al. 2004; Kaleka 2011; Griffith 2011). Lengler et al. (2013) also demonstrates that the more financial resources committed by the firm to support exporting activities, the greater its export performance. Furthermore, Wiklund and Shepherd (2005) suggest that financial resources significantly impact smaller firms such as SMEs. They have also found that learning and entrepreneurial strategies, to become competitive capabilities, require considerable financial resources to gain superior performance in the international market. Therefore, we proposed the following hypothesis:

Hypothesis $\mathbf{1}\left(\mathbf{H}_{\mathbf{1}}\right)$ : Financial support positively influences export performance.

\subsection{Marketing Support and Export Performance}

According to Indrawati et al. (2018), export marketing strategy, the firm and management characteristics are the most prominent internal determinants observed by Sousa, MartínezLópez, and Coelho 2008. In the developing country, smaller firms might not be able to afford expensive means of acquiring those experienced international marketing managers, requiring 
the government's experiential marketing assistance. These types of assistance can be in different forms such as through various trade mobility programs, local and international trade exhibitions and other offers (Kotabe and Czinkota 1992; Leonidou et al. 2011).

The expensive means of acquiring export-related marketing knowledge is not affordable by most developing country firms (Egan and Mody 1992). The government's marketing assistance such as arranging trips abroad, and taking part in foreign trade missions, local and international trade exhibitions could provide the firms with the platform to be recognised internationally (Riddle and Gillespie 2003). Therefore, this research proposed the following hypothesis to be tested:

Hypothesis $2\left(\mathbf{H}_{\mathbf{2}}\right)$ : Marketing support positively influences export performance.

\subsection{Financial Support and Competitive Capabilities}

According to Lengler et al. (2013), a significant conclusion drawn from the previous research is that financial support does not appear in the existing literature dealing with SMEs' export performance. However, a paper dealing with the competitive capabilities and export performance from Ling-Yee and Ogunmokun (2001) bolsters the fact that financing assets positively affects competitive capabilities and improves export performance.

Aside from that, Sousa et al. (2008) distinguished the effect of governments support programs and non-governmental supports on export performance. When those resources are sponsored, they can use them as extra resources to cope with their exporting expenses. The study of Morgan et al. 2004 is among those studies that illustrated that the availability of financial resources for export activities would significantly impact export venture performance outcomes (Morgan et al. 2004). Firms that gained financial support from the government can position themselves in a better place to improve exports. Therefore, this research proposed the following hypothesis to be tested:

Hypothesis $3\left(\mathbf{H}_{3}\right)$ : Financial support positively influences competitive capabilities of SMES towards internationalisation.

\subsection{Marketing Support and Competitive Capabilities}

Resources cannot be transformed into value offerings in the foreign marketplace without any marketing implementation capabilities. According to Fang and Zou (2009), marketing implementation capabilities are directly related to the firm's success in adapting to its unfamiliar foreign market environment.

Chen et al. (2016) proposed that superior export performance can be driven by enhancing a firm's marketing implementation capabilities. Managers have little information about altering the resource base when the firm steps into unfamiliar and potentially more challenging foreign markets. With the assistance of the information-related export promotion programs provided by the government, managers understand the target export market for now and in the near future (Chen et al. 2016). This will also then contribute to the better allocation of organisational resources for implementing marketing decisions with effectiveness and efficiency. Thus, in line with the research of Chen et al. (2016), the authors proposed that competitive capabilities mediate the relationship between marketing support and export performance. We conclude that marketing assistance leads to competitive capabilities in the export market (Indrawati et al. 2018), Thus we propose the following hypothesis:

Hypothesis $4\left(\mathbf{H}_{\mathbf{4}}\right)$ : Marketing support positively influences the competitive capabilities of SMEs towards internationalisation.

\subsection{Competitive Capabilities and Export Performance}

Export performance may be perceived as one of the fundamental competitiveness indicators for small economies whose economic growth is primarily determined by exports 
(Ruzekova et al. 2020). The institutional impact on export performance was identified as one of the important factors of competitiveness (Ruzekova et al. 2020).

Based on Indrawati et al. (2018), the authors had explicitly highlighted that those firms that are interested in going for internationalisation must be able to acquire information and knowledge from government sources and physical and human resources from internal sources to gain competitive advantage.

Gençtürk and Kotabe (2001) found a positive relationship between export assistance and export performance. Theoretically, the relational between export assistance and export performance of a firm supported by the resource-based view (Barney 1986; Morgan and Hunt 1999), and the knowledge-based view (Conner and Prahalad 1996; Grant 1991).

Following the firm's resource-based view (Barney 1986), Barney emphasised that the cost of acquiring resources must be lower than the gains to result in a truly competitive advantage. These resources can be obtained from external determinants, such as government assistance for both marketing support and financial support. The firm can view exporting as a low-cost entry into new foreign markets when the firm received government assistance (Morgan and Hunt 1999).

Marketing assistance by a government is more beneficial when combined with the firm's owners' competitive capabilities. This is because the information will be better internalised and leads to competitive capabilities, which positively influence the internationalising of a firm (Knight and Liesch 2002). Therefore, we propose the following hypotheses:

Hypothesis $\mathbf{5}\left(\mathbf{H}_{5}\right)$ : Competitive capabilities positively influence export performance.

Hypothesis $\mathbf{6}\left(\mathbf{H}_{\mathbf{6}}\right)$ : Competitive capabilities mediate the relationship between financial support and export performance.

Hypothesis $7\left(\mathbf{H}_{7}\right)$ : Competitive capabilities mediate the relationship between marketing support and export performance.

Figure 1 shows the research model that examines government assistance, such as financial and marketing support on firms' export performance. This research explains the relationship between financial and marketing support on export performance. This research also argues that the relationship between the two-government export supports is directional on competitive capabilities and competitive capabilities act as a mediator in the relationship of government export supports and export performance.

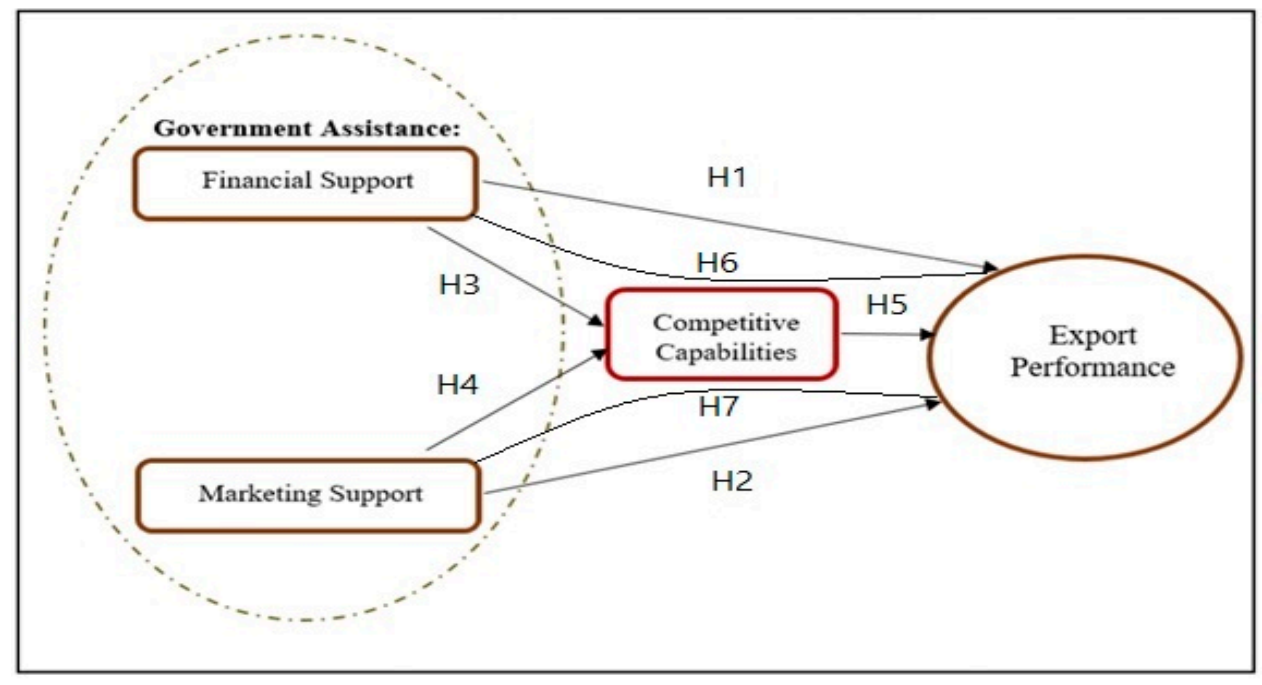

Figure 1. Research model. 


\section{Methodology}

We have chosen Malaysia as the focus of this study. Malaysia has an important southeast Asian economy and has common characteristics with other emerging markets in the region. Malaysian SMEs still face low levels of technological capacity, skilled human capital resources, levels of technology and information and communications technology penetration, research and development and internal sourcing of funds which are the common feature of emerging markets (Falahat et al. 2020b). Thus, this study's findings can generally be extended to other emerging markets especially in south-east Asia. While Malaysia's path to economic development differs from those of advanced economies, it could serve as a model of small open economies (SMOPECs) of the Southeast Asian region. The directory of the Malaysia External Trade Development Corporation (MATRADE) was used as the sampling frame. The sample was drawn from the manufacturing and services sector in Malaysia. We have filtered the sampling frame to active internationalised SMEs which have at least $25 \%$ of export sales. The email was sent along with the online survey to a total of 1000 firms. A total number of 217 questionnaires were received from the owner, CEO or senior managers of SMEs within Klang Valley. The response rate was $22 \%$ which is consistent with similar studies in the same context (Falahat et al. 2020a).

The majority of respondents were in the trading and retail sector $(39.63 \%), 36.87 \%$ of respondents were from the manufacturing sector, $14.75 \%$ of respondents were from services and warehousing, $4.60 \%$ from agriculture and $4.15 \%$ construction. The measurement scales were adapted from previous studies with a sufficient level of reliability. We use three items to measure financial and three items to measure marketing government support, adapted from Leonidou et al. (2011). We used three items from Pham et al. (2017) to measure competitive capability and eight items to measure international performance which was adapted from Falahat and Migin (2017); Falahat et al. (2018b). All measurements were made using a five-point Likert scale. Experts' advice was sought, and a pre-test was performed to finalise the questionnaire before distribution.

\section{Data Analysis}

Partial least squares structural equation modelling (PLS-SEM) was used for data analysis (Hair et al. 2014). PLS-SEM analysis was carried out by running a PLS algorithm, including a bootstrapping and blindfolding technique, using SmartPLS v.3.2.8 software. The reliability and validity of the measurement model were assessed before hypotheses testing. Table 1 shows the convergent validity and internal consistency of all constructs was established according to the rule of thumb suggested by Hair et al. 2014. Composite reliability should be above 0.708 , and the average variance extracted should be above 0.50 for reflective constructs. To address common method variance (CMV) and multicollinearity issues, all variance inflation factor (VIF) values were assessed and confirmed that all values are below 5, showing no CMV and multicollinearity issues (Diamantopoulos and Winklhofer 2001). In addition, we carried out a $t$-test to examine the non-response bias, and we found no significance (Armstrong and Overton 1977).

Table 1. Reliability and convergent validity assessment.

\begin{tabular}{|c|c|c|c|c|c|}
\hline Constructs & Items & Descriptions & Loadings & AVE & CR \\
\hline \multirow{3}{*}{ Marketing Support } & MK_SUP1 & Export market opportunities & 0.927 & 0.954 & 0.874 \\
\hline & MK_SUP2 & Information on business matching & 0.935 & & \\
\hline & MK_SUP3 & Information on the market overview & 0.943 & & \\
\hline \multirow{3}{*}{ Financial Support } & FIN_SUP1 & Soft loans & 0.941 & 0.944 & 0.849 \\
\hline & FIN_SUP2 & Grant & 0.924 & & \\
\hline & FIN_SUP3 & Tax incentives & 0.898 & & \\
\hline \multirow{3}{*}{$\begin{array}{c}\text { Competitive } \\
\text { Capability }\end{array}$} & $\mathrm{CC} 1$ & Adjust products to fit demands and tasts & 0.934 & 0.959 & 0.887 \\
\hline & $\mathrm{CC} 2$ & Develop new products for export markets & 0.956 & & \\
\hline & CC3 & Manage new product development & 0.934 & & \\
\hline
\end{tabular}


Table 1. Cont.

\begin{tabular}{clccc}
\hline Constructs & Items & Descriptions & Loadings & AVE \\
\hline & EXP_PERF1 & Profits from export sales & 0.925 & 0.977 \\
& EXP_PERF2 & Export sales & 0.915 & 0.843 \\
Export & EXP_PERF3 & Expanding market coverage & 0.9 & \\
Performance & EXP_PERF4 & Export sales to total sales & 0.912 & \\
& EXP_PERF5 & Entering new market segments & 0.931 & \\
& EXP_PERF6 & Product presence in a foreign market & 0.913 \\
& EXP_PERF7 & Improving knowledge of foreign markets & 0.923 \\
& EXP_PERF8 & product acceptance by customer & 0.926 \\
\hline
\end{tabular}

We have deployed the heterotrait-monotrait ratio (HTMT) to examine discriminant validity (Henseler et al. 2015). The confidence intervals for all HTMT values for the lower $(2.5 \%)$ and higher (97.5\%) bounds do not include 1 (Henseler et al. 2015). Hence, as presented in Table 2 all constructs are distinctive; thus, discriminant validity is not an issue.

Table 2. Discriminant validity (heterotrait-monotrait ratio, HTMT).

\begin{tabular}{ccccc}
\hline Descriptions & Original Sample (O) & Sample Mean (M) & $\mathbf{2 . 5 0 \%}$ & $\mathbf{9 7 . 5 0 \%}$ \\
\hline EXP_PERF $\rightarrow$ CC & 0.954 & 0.954 & 0.932 & 0.973 \\
FIN_SUP $\rightarrow$ CC & 0.702 & 0.7 & 0.605 & 0.781 \\
FIN_SUP $\rightarrow$ EXP_PERF & 0.736 & 0.735 & 0.65 & 0.809 \\
MK_SUP $\rightarrow$ CC & 0.823 & 0.823 & 0.764 & 0.874 \\
MK_SUP $\rightarrow$ EXP_PERF & 0.849 & 0.849 & 0.807 & 0.889 \\
MK_SUP $\rightarrow$ FIN_SUP & 0.925 & 0.924 & 0.861 & 0.975 \\
\hline
\end{tabular}

\section{Results}

This paper employed PLS-SEM to examine the hypotheses. By running a bootstrap procedure with 5000 resamples, hypotheses were tested at below 0.01 significance level. Hypotheses testing is presented in Table 3 for direct relationships and mediating effects. As shown in Table 3, financial support and export performance (H1) were not supported. Financial support and competitive capabilities (H3) were also found not to be supported, indicating a non-significant relationship. Marketing support was found to be positively related to export performance (H3). Hypothesis 4 was confirmed, indicating the positive relationship between marketing support and competitive capabilities. Competitive capabilities were also positively related to export performance (H5).

Table 3. Hypotheses results.

\begin{tabular}{cccccccc}
\hline Hypothesis & Descriptions & Std_Beta & Std_Error & T-Value & $p$-Values & F $^{2}$ & Decision \\
\hline H1 & FIN_SUP $\rightarrow$ EXP_PERF & 0.04 & 0.058 & 0.694 & 0.488 & 0.003 & Not Supported \\
H2 & MK_SUP $\rightarrow$ EXP_PERF & 0.235 & 0.066 & 3.567 & 0 * & 0.078 & Supported \\
H3 & FIN_SUP $\rightarrow$ CC & 0.004 & 0.077 & 0.046 & 0.963 & 0.000 & Not Supported \\
H4 & MK_SUP $\rightarrow$ CC & 0.765 & 0.068 & 11.333 & 0 & 0.395 & Supported \\
H5 & CC $\rightarrow$ EXP_PERF & 0.704 & 0.037 & 18.885 & $0 *$ & 1.450 & Supported \\
H6 & FIN_SUP $\rightarrow$ CC $\rightarrow$ EXP_PERF & 0.002 & 0.054 & 0.046 & 0.963 & Not Supported \\
H7 & MK_SUP $\rightarrow$ CC $\rightarrow$ EXP_PERF & 0.539 & 0.057 & 9.527 & $0 *$ & Supported \\
\hline
\end{tabular}

Note: ${ }^{*} p<0.01$.

For testing mediation, the bootstrapping procedure was conducted. This is the most recommended approach for testing mediation in the PLS-SEM context (Hair et al. 2014). The indirect relationships together with the hypothesis testing results are presented in Table 3. The results of the statistical analysis did not find support for hypotheses H6. In contrast, findings indicated that competitive capabilities mediate the relationship between marketing support and SMEs' export performance and, thus, hypothesis H7 was confirmed. 
Based on the R square results, the research model explained $60 \%$ of competitive capabilities variance and $85 \%$ of SMEs' export performance variance. The VIF was examined to identify multicollinearity issue. Since all VIF values were below 5 , thus multicollinearity was not an issue among the exogenous latent constructs. Also, the predictive relevance of the model met the rule of thumb of Q2 > 0 (Hair et al. 2014).

\section{Discussion}

It is concluded that financial support and competitive capabilities, and financial support and export performance are not significant. This result is consistent with the findings of Joo and Suh (2017) and Falahat et al. (2020b) that the direct relationship between government support and performance is vague and the relationship is negative or insignificant. According to Lengler et al. (2013), the export financing constraints faced due to complex trade instruments, lack of organisational resources, and exporters' operation size will only partly affect SMEs' performance. This is because there is still discrimination against non-state SMEs existing in the country and the processing time in releasing the government's financial assistance is longer compared to those financial institutions such as bankers.

The relationship between marketing support and export performance (H2) was found to be positively significant. Our findings supported by Riddle and Gillespie (2003) study that the government's marketing assistance such as an arrangement for overseas trips and organisation of foreign trade missions and international trade exhibitions could provide the firms with the platform to be internationally recognised.

We found that the relationship between marketing support and competitive capabilities is positively significant (H4). Our findings are consistent with Chen et al. (2016) research, which proposed that marketing support have a relationship with the export performance mediated by the implementation of competitive capabilities. This is because marketing support acted as an essential resource for efficient and effective decision making.

The relationship between competitive capabilities and export performance (H5) is positively significant. According to Knight and Liesch (2002), the combination of the government's marketing assistance with the competitive capabilities of early internationalphase firms will have more impact.

Our research also investigates the mediation role of competitive capabilities between financial support and marketing support on the export firm's performance. Consistent with the study of Indrawati et al. (2018), competitive capabilities are proposed as the mediator which acts as an essential determinant of export performance.

\section{Limitations, Recommendations, and Implications}

This study has three important limitations. First, it employed a quantitative method focusing on Malaysian manufacturers and service sectors at Klang Valley, Malaysia. The lack of geographic diversity limits the generalisability of the findings. Second, relatively sample size due to budget and time constraints, only 217 valid responses were received. Third, this study only considered the direct relationship between government assistance (marketing and financial supports), competitive capabilities and export performance, without taking into consideration the control variables such as firm's size, age and industries.

It is recommended for the future to conduct a study across all industries and states to overcome the limitation of generalisability. Also, it is suggested that scholars for future studies employ multilevel causal factors to assess the strategic success and performance of SMEs as recommended by Chankoson (2019).

This study found that government support plays an essential role in improving SMEs capabilities and performance. SMEs in Malaysia are small in size, and they need support in both marketing and finance for internationalisation growth. Our research shows that marketing support also has a positive impact on a firm's export performance. This shows that providing information, specifically on export market opportunities, organising export seminars, conferences, training programs, and counselling advice, would definitely help SMEs in gaining competitiveness and enhance their growth internationally. Thus, it is rec- 
ommended that SMEs consider participating in several government support programmes when formulating their international strategies. Future studies may consider the effects of institutional support across all sectors in the wider geographic areas and also consider analysing the multidimensional barriers (Pietrasieński and Ślusarczyk 2015) that SMEs face in their expansion into foreign markets.

\section{Conclusions}

Generally, this paper proposed that institutional support in the form of marketing and financial support from the government are two critical factors for resource-poor SMEs to achieve competitive capabilities and gain international performance. We found that financial support does not translate into competitive capabilities and firms' performance, but marketing support reflects strongly on firms' competitive capabilities and leads to firms' performance in international markets.

Author Contributions: All authors contributed equally. All authors have read and agreed to the published version of the manuscript.

Funding: This research received no external funding.

Institutional Review Board Statement: The study was conducted according to the ethical guidelines of the declaration approved by UTAR ethical committee (Reference No: U/SERC/127/2020 dated 27 August 2020).

Informed Consent Statement: Informed consent was obtained from all participants prior to the commencement of the research.

Data Availability Statement: The data presented in this study are available on request from the corresponding author. The data are not publicly available due to the confidentiality of participants personal data.

Acknowledgments: The authors acknowledge the model research in this study.

Conflicts of Interest: The authors declare no conflict of interest.

\section{References}

Ahmad, Syed Zamberi, and Siri Roland Xavier. 2002. Entrepreneurial Environments and Growth: Evidence from Malaysia GEM Data. Journal of Chinese Entrepreneurship 4: 50-69. [CrossRef]

Ahmed, Zafar Uddin, Osman Mohamed, James Johnson, and Leong Yee Meng. 2002. Export promotion programs of Malaysian firms: An international marketing perspective. Journal of Business Research 55: 831-43. [CrossRef]

Albaum, Gerald Strandskov, Jesper, and Edwin Duerr. 1998. International Marketing and Export Management. Harlow: Addison-Wesley.

Armstrong, Scott, and Terry Overton. 1977. Estimating nonresponse bias in mail surveys. J. Mark. Res. 14: 396-402. [CrossRef]

Badulescu, Daniel. 2010. SMEs Financing: The Extent of Need and the Responses of Different Credit Structures. Theoretical and Applied Economics 17: 25-36.

Barney, Jay. 1986. Organizational Culture: Can It Be A Source of Sustained Competitive Advantage? The Academy of Management Review 11: 656-65. [CrossRef]

Barney, Jay. 1991. Firm Resources and Sustained Competitive Advantage. Journal of Management 17: 99-120. [CrossRef]

Barney, Jay. 2012. Purchasing, Supply Chain Management and Sustained Competitive Advantage: The Relevance of Resource-Based Theory. Journal of Supply Chain Management 48: 3-6. [CrossRef]

Baumann, Renato, and Helson Braga. 1988. Export Financing in LDCs: The Role of Subsidies for Export Performance in Brazil. World Development 16: 821-33. [CrossRef]

Beck, Thorsten, Asli Demirgüç-Kunt, and Vojislav Maksimovic. 2008. Financing Patterns Around the World: Are Small Firms Different? Journal of Financial Economics 89: 467-87. [CrossRef]

Bilkey, Warren, and George Tesar. 1977. The Export Behavior of Smaller Wisconsin Manufacturing Firms. Journal of International Business Studies 8: 93-98. [CrossRef]

Cavusgil, Tamer. 1980. On the Internationalisation Process of Firms. European Research 8: 273-81.

Cavusgil, Tamer, and Shaoming Zou. 1994. Marketing Strategy-Performance Relationship: An Investigation of the Empirical Link in Export Market Ventures. Journal of Marketing 58: 1-21. [CrossRef]

Chankoson, Thitinan. 2019. Multilevel causal factors affecting the strategic success of thai export businesses. Polish Journal of Management Studies 19: 94-105. [CrossRef]

Chen, Chien-Hsun, Chao-Cheng Mai, and Hui-Chuan Yu. 2006. The Effect of Export Tax Rebates on Export Performance: Theory and Evidence from China. China Economic Review 17: 226-35. [CrossRef] 
Chen, Jieke, Carlos M. P. Sousa, and Xinming He. 2016. Export Performance Research: A Review of Literature 2005-2014. International Marketing Review 5. [CrossRef]

Conner, Kathleen, and Coimbatore Krishnarao Prahalad. 1996. A Resource-Based Theory of the Firm: Knowledge Versus Opportunism. Organization Science 7: 477-501. [CrossRef]

Crick, Dave. 1995. An Investigation into the Targeting of U.K. Export Assistance. European Journal of Marketing 29: 76-94. [CrossRef]

Czinkota, Michael. 1994. A National Export Assistance Policy for New and Growing Businesses. Journal of International Marketing 2: 91-101. [CrossRef]

De Chiara, Alessandra, and Antonio Minguzzi. 2002. Success Factors in SMEs' Internationalisation Process: An Italian Investigation. Journal of Small Business Management 40: 144-53. [CrossRef]

Diamantopoulos, Adamantios, and Susan Hart. 1993. Marketing Research Activity and Company Performance: Evidence from Manufacturing Industry. European Journal of Marketing 27: 54-72.

Diamantopoulos, Adamantios, and Heidi Winklhofer. 2001. Index construction with formative indicators: An alternative to scale development. Journal of Marketing Research 38: 269-77. [CrossRef]

Durmuşoğlu, Serdar, Apfelthaler Gerhard, Nayir Dilek Zamantili, Alvarez Roberto, and Mughan Terry. 2012. The Effect of GovernmentDesigned Export Promotion Service Use on Small and Medium-Sized Enterprise Goal Achievement: A Multidimensional View of Export Performance. Industrial Marketing Management 41: 680-91. [CrossRef]

Egan, Mary Lou, and Ashoka Mody. 1992. Buyer-Seller Links in Export Development. World Development 20: 321-34. [CrossRef]

Egena, Ode, Dinnah Ngovenda Wombo, Ede Ekpe Theresa, and Mile Ngodoo Bridget. 2014. Institutional Support for Small and Medium Enterprises in Nigeria: An Empirical Investigation. International Journal of Economy, Management and Social Sciences 3: 481-89.

Falahat, Mohammad, Yan-Yin Lee, Pedro Soto-Acosta, and Thurasamy Ramayah. 2021. Entrepreneurial, market, learning and networking orientations as determinants of business capability and international performance: The contingent role of government support. International Entrepreneurship and Management Journal 1-22. [CrossRef]

Falahat, Mohammad, Thurasamy Ramayah, Pedro Soto-Acosta, and Yan Yin Lee. 2020a. SMEs internationalisation: The role of product innovation, market intelligence, pricing and marketing communication capabilities as drivers of SMEs' international performance. Technological Forecasting and Social Change 152: 119908. [CrossRef]

Falahat, Mohammad, Yan-Yin Lee, Thurasamy Ramayah, and Pedro Soto-Acosta. 2020b. Modelling the effects of institutional support and international knowledge on competitive capabilities and international performance: Evidence from an emerging economy. Journal of International Management 26: 100779. [CrossRef]

Falahat, M., and Melissa Wendy Migin. 2017. Export performance of international new ventures in emerging market. International Journal of Business and Globalization 19: 111-25. [CrossRef]

Falahat, Mohammad, Gary Knight, and Ilan Alon. 2018a. Orientations and Capabilities of Born Global Firms from Emerging Markets. International Marketing Review 35: 936-57. [CrossRef]

Falahat, Mohammad, Shehnaz Tehseen, and Constance Van Horne. 2018b. Entrepreneurial Innovativeness and Its Impact on SMEs' performances. International Journal of Entrepreneurship 22: 1-9.

Fang, Eric Er, and Shaoming Zou. 2009. Antecedents and Consequences of Marketing Dynamic Capabilities in International Joint Ventures. Journal of International Business Studies 40: 742-61. [CrossRef]

Freeman, Robert Edward. 2007. The Resource-Based View: Origins and Implications. In Handbook of Strategic Management. Oxford: Blackwell, pp. 124-88.

Gençtürk, Esra F., and Masaaki Kotabe. 2001. The Effect of Export Assistance Program Usage on Export Performance: A Contingency Explanation. Journal of International Marketing 9: 51-72.

Grant, Robert Morris. 1991. The Resource-Based Theory of Competitive Advantage: Implications for Strategy Formulation. California Management Review 33: 14-135. [CrossRef]

Griffith, David A. 2011. Insights into Gaining Access to Export Financing: Understanding Export Lenders' Ideal Exporter Profile. Journal of World Business 46: 84-92. [CrossRef]

Griffith, David A., and Michael Czinkota. 2012. Release the Constraints: Solving the Problems of Export Financing in Troublesome Times. Business Horizons 55: 251-60. [CrossRef]

Hair, Joseph F., Jr., Tomas Hult, Christian Ringle, and Marko Sarstedt. 2014. A Primer on Partial Least Squares Structural Equations Modeling (PLS-SEM). Thousand Oaks: SAGE.

Hassan, Adewale Samuel, Daniel Francois Meyer, and Sebastian Kot. 2019. Effect of institutional quality and wealth from oil revenue on economic growth in oil-exporting developing countries. Sustainability 11: 3635. [CrossRef]

Hagen, Birgit, and Antonella Zucchella. 2014. Born global or born to run? The long-term growth of born global firms. Management International Review 54: 497-525. [CrossRef]

Henseler, Jörg, Christian M. Ringle, and Marko Sarstedt. 2015. A new criterion for assessing discriminant validity in variance-based structural equation modeling. Journal of the Academy of Marketing Science 43: 115-35. [CrossRef]

Hoque, Abu Shams Mohammad Mahmudul. 2018. Does Government Support Policy Moderate the Relationship Between Entrepreneurial Orientation and Bangladeshi SME Performance? A SEM Approach. International Journal of Business Economics and Management Studies 6: 37-59. 
Indrawati, Nur Khusniyah, Setyo Purwanto, Fatchur Rohman, and M. Setiawan. 2018. Financial Assistance, Marketing Assistance and Export Commitment to Improve Export Performance. European Research Studies Journal 21: 69-91.

Iweka, Hector, Abiola Babajide, and Felicia Omowunmi Olokoyo. 2016. Dynamics of Small Business in an Emerging Market: Challenges and Opportunities. Paper presented at 3rd International Conference on African Development Issues, Ota, Nigeria, May 9-11; pp. 91-99.

Johanson, Jan, and Jan-Erik Vahlne. 1990. The Mechanism of Internationalisation. International Marketing Review 7: 11-24. [CrossRef]

Johanson, Jan, and Finn Wiedersheim-Paul. 1975. The Internationalisation of the Firm: Four Swedish Cases. Journal of Management Studies 12: 305-22. [CrossRef]

Joo, Hye-Young, and Hyunsuk Suh. 2017. The Effect of Government Support on Corporate Performance Hedging against International Environmental Regulation. Sustainability 9: 1980. [CrossRef]

Kaleka, Anna. 2011. When exporting manufacturers compete on the basis of service: Resources and marketing capabilities driving service advantage and performance. Journal of International Marketing 19: 40-58. [CrossRef]

Katsikeas, Constantine S. 1994. Export Competitive Advantages: The Relevance of Firm Characteristics. International Marketing Review 11: 33-53. [CrossRef]

Knight, Gary, and Peter Liesch. 2002. Information Internalisation in Internationalising the Firm. Business Research 55: 14-21. [CrossRef]

Kolarov, Kostadin, and Silviya Georgieva. 2020. Management features in Bulgarian SMEs as determinants of business internationalization. Polish Journal of Management Studies 22: 279-94. [CrossRef]

Kotabe, Masaaki, and Michael Czinkota. 1992. State Government Promotion of Manufacturing Exports: A Gap Analysis. Journal of International Business Studies, Fourth Quarter 23: 637-58. [CrossRef]

Lee, Yan Yin, Mohammad Falahat, and Bik Kai Sia. 2019. Impact of Digitalization on the Speed of Internationalisation. International Business Research 12: 1-11. [CrossRef]

Lee, Yan Yin, Mohammad Falahat, and Bik Kai Sia. 2020. Drivers of digital adoption: A multiple case analysis among low and high-tech industries in Malaysia. Asia-Pacific Journal of Business Administration 13: 80-97. [CrossRef]

Lengler, Jorge, Carlos M. P. Sousa, Marcelo Gattermann Perin, Cláudio Hoffmann Sampaio, and Francisco J. Martínez-López. 2013. The Antecedents of Export Performance of Brazilian SMEs: The Non-Linear Effects of Customer Orientation. International Small Business Journal 34. [CrossRef]

Leonidou, Leonidas, Dayananda Palihawadana, and Marios Theodosiou. 2011. National Export-Promotion Programs as Drivers of Organizational Resources and Capabilities: Effects on Strategy, Competitive Advantage, and Performance. Journal of International Marketing 19: 1-29. [CrossRef]

Ling-Yee, Li, and Gabriel O. Ogunmokun. 2001. The Influence of Interfirm Relational Capabilities on Export Advantage and Performance: An Empirical Analysis. International Business Review 10: 399-420. [CrossRef]

Martinez-Conesa, Isabel, Pedro Soto-Acosta, and Elias George Carayannis. 2017. On the path towards open innovation: Assessing the role of knowledge management capability and environmental dynamism in SMEs. Journal of Knowledge Management 21: 553-70. [CrossRef]

Morgan, Neil, Anna Kaleka, and Constantine Katsikeas. 2004. Antecedents of Export Venture Performance: A Theoretical Model and Empirical Assessment. Journal of Marketing 68: 90-108. [CrossRef]

Morgan, Robert, and Shelby Hunt. 1999. Relationship-Based Competitive Advantage: The Role of Relationship Marketing in Marketing Strategy. Journal of Business Research 46: 281-90. [CrossRef]

Morgan, Neil, and Douglas Vorhies. 2005. Benchmarking Marketing Capabilities for Sustainable Competitive Advantage. Journal of Marketing 69: 80-94.

Naidu, G. M., and T. R. Rao. 1993. Public Sector Promotion of Exports: A Needs Based Approach. Journal of Business Research $27:$ 85-101. [CrossRef]

National SME Development Council. 2015. SME Corporation Malaysia. Available online: http:/ /www.smecorp.gov.my/index.php/ en/about/2015-12-21-08-40-32/nsdc (accessed on 2 April 2019).

Navarro, Antonio, Francisco Acedo, Matthew Robson, Emilio Ruzo, and Fernando Losada. 2010. Antecedents and Consequences of Firms' Export Commitment: An Empirical Study. Journal of International Marketing 18: 41-61. [CrossRef]

Oboreh, Jacob, Umukoro Francis, and Ayozie Daniel Ogechukwu. 2013. SMEs in Nigeria and the Use of Relationship Marketing Strategy: A Survey Study of IGBO SMEs in Nigeria. Global. Journal of Management and Business Research Marketing 13: 49-75.

Penrose, Edith Tilton. 1959. The Theory of the Growth of the Firm. New York: Oxford University Press.

Pietrasieński, Paweł, and Beata Ślusarczyk. 2015. Internationalization of small and medium enterprises-Empirical research review on barriers to entry into foreign markets. Polish Journal of Management Studies 11: 113-23.

Pham, Thi Song Hanh, Lien Le Monkhouse, and Bradley R. Barnes. 2017. The Influence of Relational Capability and Marketing Capabilities on The Export Performance of Emerging Market Firms. International Marketing Review 34: 606-28. [CrossRef]

Reid, Stan. 1981. The Decision-Maker and Export Entry and Expansion. Journal of International Business Studies 12: 101-12. [CrossRef]

Rennie, Michael. 1993. Born global. The McKinsey Quarterly 4: 45-53.

Riddle, Liesl, and Kate Gillespie. 2003. Information Sources for New Ventures in the Turkish Clothing Export Industry. Small Business Economics 20: 15. [CrossRef]

Rufaidah, Popy. 2017. The determinants of marketing capability for SMEs. Journal for Global Business Advancement 10: 671-700. [CrossRef] 
Rufaidah, Popy. 2019. Entrepreneurial orientation of SMEs in the creative fashion industry. Journal for Global Business Advancement 12: 254-75. [CrossRef]

Ruzekova, Viera, Zuzana Kittova, and Dusan Steinhauser. 2020. Export performance as a measurement of competitiveness. Journal of Competitiveness 12: 145-60. [CrossRef]

Seringhaus, F. H. Rolf. 1986. The Impact of Government Export Marketing Assistance. International Marketing Review 3: 55-66. [CrossRef]

Souchon, Anne, and Adamantios Diamantopoulos. 1996. A Conceptual Framework of Export Marketing Information Use: Key Issues and Research Propositions. Journal of International Marketing 4: 49-71. [CrossRef]

Sousa, Carlos MP, Francisco J. Martínez-López, and Filipe Coelho. 2008. The Determinants of Export Performance: A Review of the Research in the Literature between 1998 and 2005. Management Reviews 10: 31. [CrossRef]

Tannous, George. 1997. Financing Export Activities of Small Canadian Businesses: Exploring the Constraints and Possible Solutions. International Business Review 6: 411-31. [CrossRef]

Wernerfelt, Birger. 1984. A Resource-Based View of the Firm. Strategic Management Journal 5: 171-80. [CrossRef]

Wiklund, Johan, and Dean Shepherd. 2005. Entrepreneurial Orientation and Small Business Performance: A Configurational Approach. Journal of Business Venturing 20: 71-91. [CrossRef]

Yeoh, Poh-Lin. 2000. Information Acquisition Activities: A Study of Global Start-Up Exporting Companies. Journal of International Marketing 8: 36-60. [CrossRef]

Zahra, Shaker A., and Gerard George. 2017. International entrepreneurship: The current status of the field and future research agenda. Strategic Entrepreneurship: Creating a New Mindset 253-88. [CrossRef]

Zia, Bilal. 2008. Export Incentives, Financial Constraints, and the (Mis)allocation of Credit: Micro-level Evidence from Subsidised Export Loans. Journal of Financial Economics 87: 498-527. [CrossRef]

Zain, Mohamed, and Siew Imm Ng. 2006. The Impacts of Network Relationships on SMEs' Internationalization Process. Thunderbird International Business Review 48: 183-205. [CrossRef] 